\title{
"Here I Stand!" Mary-Anne Elizabeth Plaatjies-Van Huffel on Blackness as Key to the Ministry of SA's Victims of Oppression
}

Tobias Masuku

https://orcid.org/0000-0001-8476-1170

University of South Africa

masukumt@penta-net.co.za

\section{Abstract}

South Africa has many victims of oppression who are materially poor. They are living in poor and unhealthy conditions, unemployed and suffering from poor government service delivery as a result of corruption. They are, therefore, angry and need relevant ministry that could address their conditions. Most of them happen to be classified as "black" and they are predominantly Christians belonging to churches. Mary-Anne Elizabeth Plaatjies-Van Huffel was a black minister in a black church that is predominantly composed of the victims of oppression. Should those who are not "black" be included or excluded in the provision of ministry to the victims of oppression? Will their ministry be relevant to the plight of these victims? What, then, is the qualification for a meaningful and transformative ministry to the victims of oppression? What is the meaning and role of "blackness" as key/qualification for relevant ministry praxis towards the victims of oppression? Plaatjies-Van Huffel left a legacy for the church, which provides a suitable leadership and response to these questions. Therefore, this article seeks to interrogate her theology of "blackness" to determine whether it excludes or includes other servants of God from ministry to these victims of oppression. In order to reach this goal, we will engage with great thinkers as her interlocutors within the scope of black theology, liberation theology, feminist theology, and African theology. The term, "blackness" will also be explored and interrogated in light of the context of this article.

Keywords: Mary-Anne Elizabeth Plaatjies-Van Huffel; blackness; liberation theologies; victims of oppression; black women; church

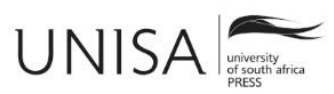




\section{Introduction}

What do I mean when I say I am Black? Does that meaning change when I am called Black or if, tomorrow, I should call you Black? ... And does the colour of my skin matter or is it the only thing that matters? In other words, do the terms Black and Blackness come to us with given meaning that is specific and non-changing, exacting a knowledge and understanding of the terms that is not based on experience alone? (Foster 2007, xi)

In a situation where black identity is placed within a theological context with regard to ministry to the victims of oppression, what about those whom Mary-Anne Elizabeth Plaatjies-Van Huffel $(2020,102)$ calls "people who do not have black skin but who do work for liberation?" Can they be allowed to minister to the victims of oppression, who still bear the marks of colonial or apartheid Christianity against which Plaatjies-Van Huffel dedicated her life to combat and eradicate? What is "blackness" in this regard? Can it stand as a key that includes or excludes others for ministry towards the victims of oppression? What qualifications does one need to minister to the victims of oppression with integrity, trust and acceptability? What is the ministry framework that is needed towards the victims of oppression? This article wrestles with these and related questions.

Who are the victims of oppression? They are defined as those, apart from carrying the marks of apartheid, are "people who were disillusioned by the Christian faith as a result of the way in which it was misused as a tool for oppression" (Masuku 2010, 1). Apart from the apartheid victims, "there is another form of post-1994 victims of oppression in South Africa made out of those who feel left out by government poverty alleviation, economic development and service delivery programmes" (Masuku 2010, ii). Another characteristic of these victims of oppression is that they are marked by anger that results into protest actions, which Masuku $(2010,5)$ defines as "mass action, i.e. protest marches followed by violence, destruction to property, littering on streets, police action and injuries." The ontological or physiological mark of "blackness" is, therefore, attached to these victims as part of their identity. Plaatjies-Van Huffel added another dimension to the scope of the identity of the victims of oppression when she warned that "the awareness of the struggle and suffering of people who are not black-skinned, across the globe, is needed" (Plaatjies-Van Huffel 2020, 103). The victims of oppression are thus currently a combination of the products of apartheid (1948-1994) and corruption of the post-1994 democratic dispensation, as described by Masuku (2010, 210):

Despite the fact that there are victims of oppression of our time that were created by the new form of oppression which is corruption and an economic system that has led to the divide between the rich and the poor, apartheid left a legacy of its own victims. The methods used to combat apartheid in the form of protests are still seen today. This means that the legacy of protest action as seen today is a continuation of that which started in the fight against apartheid. That legacy is therefore, passed on from generation to generation. 
What about those who are not identified along the lines of "blackness" in terms of acceptability in ministering to the victims of oppression? What muthi (magic) or qualification will they need in order to gain access or acceptability to a trusted transformative ministry to the victims of oppression? What, then, is the paradigm for a relevant ministry in a situation of blackness? This article attempts to seek answers from the mind of Plaatjies-Van Huffel.

\section{Survey of the Debate on the Term "Blackness"}

In order to fully grasp Plaatjies-Van Huffel's stance in the context of this article, it is important to understand the dynamics around this term, "blackness." The concept "black" or "blackness" is among the most debated in both academic and socio-political spaces. What did Plaatjies-Van Huffel (2013a, 331) mean by "black Reformed Christians in South Africa?" who with the World Alliance of Reformed Churches (WARC) declared that apartheid is sin? What did she mean by what she called "black Dutch Reformed Church (DRC)?" (Plaatjies-Van Huffel 2013a, 339). When discussing the origin and development of church racism in South Africa, tracing it from as early as 1829 (especially 29 April 1829) on how the DRC congregation of Swartland in the presbytery of Cape Town dealt with racism on Holy Communion in relation to new converts, she employed such terms as "indigenous people, black, mixed decent, slaves" (Plaatjies-Van Huffel 2013a, 332). The name of this congregation under review is Swartland in Afrikaans and is literally translated to mean "Black Land" in English. Ironically, it implies "land of the blacks." The Dutch language that was used to refer to those new converts was "personen van die kleur" (Plaatjies-Van Huffel 2013a, 332). She reveals that the synods of DRC for the years 1834, 1837, and 1857 employed the term "gentiles" (Plaatjies-Van Huffel 2013a, 333), which is originally from the Hebrew word goyim, thus with a definite article "ha-goyim," meaning non-Jewish persons (or nations). During the ongoing debate at this period, terms such as "natives" and "heathens" also featured with reference to the position of new converts in the DRC (Plaatjies-Van Huffel 2013a, 333). She also used the term "African people" with reference to members of the DRCA after the DRC synod of 1957 divided the new converts along racial lines (Plaatjies-Van Huffel 2013a, 335). At some instances she used the expressions "people of colour" and "indigenous people." She also addressed the oppressed people of South Africa (SA) as "blacks" (Plaatjies-Van Huffel 2013a). When discussing the division of the DRC into different race groups, terms such as “"bantoekerk'; 'coloured' (in inverted commas); and 'people of colour' were employed" (Plaatjies-Van Huffel 2013a).

The 2020 Miss Universe, Zozi Tunzi (2020), while interviewed in an African perspective programme on eNCA TV, employed the expression; "people of colour"

1 According to the Chicago Manual of Style (2017, 8.38, 476), "terms such as black and white, when referring to ethnicity, are usually lowercased [if not in a title or direct quote] ... unless a particular author or publisher prefers otherwise." "Names of ethnic and national groups [proper nouns] are capitalised." The author has adhered to this style. 
when referring to supporters of Black Lives Matter (BLM) in the USA. Fatton (1986, $29)$ employs the term "masses" in reference to victims of oppression. Bennett $(2009,1)$ divided the oppressed into "Africans, blacks and mulattos" while indicating how the Roman Catholic Church (RCC) supported their slavery and subjugation in colonial Mexico during the 17th century. In some instances, he refers to "non-whites" and "near whites" (Bennett 2009, 137). Curran (2011, 1), in addressing the anatomy of blackness, refers to "black Africans." In further enquiring about the categorisation of what he called "black humans" in the early modern era, he indicated how it slowly crystallised into "black race" up until when it was "black African."

Foster (2007, xv) holds that "black" and "blackness" are two different consciousnesses. The same is true for consciousnesses that are white and whiteness. These consciousnesses, however, share social order and exist together in a lordship and bondage relationship that is characterised by a dominance of the entire order. Foster (2007, xv) further holds that multiculturalism is part of the consciousness of "blackness" and that at least ontologically, epistemologically and ethically, multiculturalism is black and an exercise in blackness. It is always in a struggle with whiteness that is marked by ethnic purity. The blackness of multiculturalism says that any group that qualifies socially belongs, and that no group has a higher ranking or sense of belonging than any other and that in terms of citizenship, all individuals and groups belong and are equal. He concludes: “... this consciousness includes even those who might not identify themselves as black, or see themselves as embedded in blackness" (Foster 2007, xvii).

Scott $(2010,4)$ examines it from another angle. He reasons that blackness is an invention that accomplishes the domination of those who bear it as an identity. For that point, blackness, while it is something that must be embraced and lionised as a first step (because it has been degraded under white supremacy); eventually it needs to be surpassed in favour of a conception of a nation that does not depend on racial definition. It is along the same line that Foster (2007, xiii) asked this rhetoric question: "Does my black blood place upon me any more obligation to assert my nationality than German, or Irish or Italian blood would?"

\section{Plaatjies-Van Huffel in Dialogue with Black Theologies of Liberation}

In interrogating the question of blackness with regard to the key towards ministry to the victims of oppression, the author will engage Plaatjies-Van Huffel's views with some theologies of liberation in order to determine her stance on them. The theologies would include; liberation theology, black theology (which will be discussed alongside the Black Consciousness Movement [BCM]), feminist theology, and African theology.

Original traces of liberation theology could be found from the Latin American Bishops' Conference that was held in Medellin in 1968; from a book by Gustavo Gutierrez entitled, A Liberation of Theology published in 1973; and from the publication of Juan Segundo's book called, The Liberation of Theology in 1975. This was a theology for people worldwide who felt the call to speak more relevantly to their age and generation, 
who freed themselves from traditional dogmatic and systematic theology and focused on life issues. Instead of telling people what questions to ask, they began to listen to the questions people were asking, and then to seek the answers. From this type of theology, other expressions of theologies developed, for example, black theology (followed by the BCM), and so forth (Oduyoye 2009, 3, 4).

Liberation theology emerged in African theology, especially among the Francophone theologians, who were focusing on the liberation of the poor instead of concentrating on the Africanising process. African theology, thus, stands for the interpretation and expressions of Christian faith by Africans. It also rules out theology done by expatriates in Africa, or relating to African culture, even if they may be researching it. From this process, African women's theology was born to empower African women; and Mercy Amba Oduyoye $(2001 ; 2005)$ emerged as its formidable agent. SA's black theology emerged as a tool for the struggle against apartheid policies (Pontinen 2013, 51).

Black theology cannot be seen in isolation from the BCM, because the latter acted as fertile ground for the birth of the former. According to Kritzinger (1988, 5), black theologians are regarded as those who have been influenced by the BCM in SA and are thus exponents of black theology. He coined the nature of this connection well when he stated that the BCM "represents the experiential base out of which black theology arose, as well as the framework within which it developed. It would not do justice to either of the movements to regards the one as 'secular' and the other as 'religious,' there is an intimate mutual relationship between the two" (Kritzinger 1988, 23). Magaziner (2010, 4) indicates that the BCM was exemplified by Steve Biko and emphasised black dignity and self-worth. The praxis of the BCM has been identified by Kritzinger $(1988,34)$ to be aiming at holistic liberation. This involves liberation from both personal inferiority feelings and the whole system of racist oppression. He called these two dimensions internal and external liberation.

In Reddie's $(2014,1)$ mind, black theology is in fact black liberation theology. He argues that "liberation" is there as an emphasis or rhetorical device. He stresses that its usage is tautological. He holds that black theology's reason for being is to espouse the theme of "liberation." He defines black theology as prophetic, liberationist, angry, polemical and passionate. He is also referring to the specific self-named discipline of re-interpreting Christian traditions and practices in the light of liberationist themes and concepts, which arise out of black experiences. This approach is one that makes blackness and black experience the initial point of departure (in partnership with scriptures and not the Bible alone, as the sole authority), and uses these sources as the primary hermeneutic lens by which the truth of God's liberating agency is discerned. Thus, blackness becomes the prime interpretive framework of re-interpreting and reimagining God and the Christian faith (Reddie 2014, 17).

Plaatjies-Van Huffel (2013a, 337) embraced these expressions of theologies of liberation. This is seen in her support for the contents of the report on "black power and 
black theology" that was tabled on the Dutch Reformed Mission Church (DRMC) Synods of 1978 and 1982. This report influenced the hermeneutic in the DRMC then. That is why the role of the church and society in apartheid SA was highlighted in the synods of the DRMC. Reddie $(2014,12)$ understands the agenda of black theology the same way as Plaatjies-Van Huffel, i.e. employment of "blackness" inclusively. He prefers using "black" because it is specific, yet inclusive of others. He argued: "It suggests coalition building and solidarity in struggle with others, and yet has a specificity for identifying themes that are central to the collective experience of being "African"" (Reddie 2014). He said: "Black theology is committed to liberative praxis and social transformation" (Reddie 2014, 14). This view supports Plaatjies-Van Huffel's approach. She argues that black identity in black theology means that "identity is not static, but rather a socio-dynamic, racialized, and historical construct. It is multiple, textured, and converging" (Plaatjies-Van Huffel 2020, 101).

In SA, Christianity, among other expressions of this faith, also flourished when it contributed to the realisation of black liberation. Black theology expressed the radical need to resuscitate Christianity from the stultifying grip of colonial and racist domination in order to restore its original prophetic essence. Christianity, according to the dominant theme of black theology, was imbued with the legacy of Jesus' identification with the oppressed, and Jesus' condemnation of the powers that be (Fatton 1986, 107).

Plaatjies-Van Huffel was also a champion of feminist theology. She pointed this out when she commented as follows on how she sees herself in this feminist theology project: "I hope that I am a vision of hope for women in and outside of the church or their own careers. My success story must be the success story for all the women" (Flaendorp 2014, 59).

Plaatjies-Van Huffel also applied her mind to the institutionalisation of women organisations. She argued that the institutionalisation of Christian women organisations in URCSA played a pivotal role in describing women as docile objects in theological discourse. Christian women's organisations, she argued later, were developed as sites for change. She reasoned that this was due to the influence of ecumenism. She pointed out that women were generally absent in URCSA during the first part of the 20th century. She noted that they only started participating in the later part of the 20th century. It is only then that they started to claim their freedom and to resist domination (Flaendorp 2014, 59).

Plaatjies-Van Huffel lamented the fact that discrimination against women in SA society still persisted despite the impressive policies for their empowerment. She then addressed the marginalisation of women in her doctoral thesis in 2003. Her topic was, "Women in the Theological Anthropology in the Afrikaans Reformed Churches." She thus, in this thesis, proposed a paradigm shift by the church towards women. She went further in her struggle for the marginalised women when she legitimised the first woman person to be 
licensed in URCSA. Under her mentorship, Bettie Wanza, a deaf woman at the school for the deaf in Worcester, completed her theological studies. From her position at the University of Stellenbosch, she assisted female theological students with their difficulties. As lecturer and woman minister, she offered advice. She held that the struggle for women is still far from over. The Curatorium of the Western Cape Synod, frequently referred students to her whenever they had problems with their calling and she would assist them from her experience as a female minister (Flaendorp 2014, 59$61)$.

Plaatjies-Van Huffel (in Conradie and Klaasen 2014, 110) was attracted to the gender section in the speech of Mandela during the first democratic parliament. Mandela emphasised that freedom could not be achieved unless women had been emancipated from all forms of oppression. He continued to point out that all of us had to take this on board, and emphasised that the objectives of the Reconstruction and Development Programme (RDP) would not have been realised unless we saw, in practical and visible terms, that the conditions of the women in our country had been changed for the better and that they had been empowered to intervene in all aspects of life, as equals with any other members of society.

The Uniting Reformed Church in Southern Africa (URCSA) accepted a gender policy in 1994 and embraced the concept of gender equality. Plaatjies-Van Huffel (in Conradie and Klaasen 2014, 113) was concerned about Reformed churches that still held back women. In this regard, she highlighted the Gereformeerde Kerk in Suid Afrika (GKSA) and the Reformed Church in Africa (RCA) as churches that resist the inclusion of women in leadership positions and ordination. These churches were, however, challenged by URCSA and the DRC, which demonstrated their commitment to having honoured the biblical mandate on this matter. She concluded by stating that "churches should acknowledge their complicity in perpetuating sexism and discrimination. They should challenge discriminatory theological formulations and work towards inclusive liturgies. Sexist practices of exclusion, silencing, marginalising other voices, direct acts, or complicity in abuses of women or children, teachings that enforce submission even in violent homes are all ways of exercising power" (Conradie and Klaasen 2014, 115).

\section{"Blackness" as an Inclusive Key for Service to the Victims of Oppression}

Plaatjies-Van Huffel's position on "blackness" as an inclusive key for service to the victims of oppression could be gleaned from early, foundational debates within the political spheres on this matter. The discourse on whether to trust the services of those who have been politically identified as white, has been a thorny one from time immemorial. For instance, in contradistinction to the multiracialism of the African National Congress (ANC), the Pan Africanist Congress (PAC), which originated in the ANC's Congress Youth League of the 1940s, preached the virtues of an undiluted African nationalism. The argument was that the employment of whites in the service 
towards the liberation project would dilute the quality of the struggle for liberation of the victims of oppression. The pursuit of a white exclusion policy by blacks would augment the quality of the black liberation project. Only such exclusively African movements, argued the PAC, could liberate Africans from their cultural inferiority, material deprivation, and social humiliation. Africans, in the PAC's Africanist view, were to no longer understand their position through European lenses, nor were they to borrow the language and practices of white liberals in their quest for liberation; rather, they were to formulate their own vision of the world and select the ways in which to transform it. Africans had to free themselves from their cultural and economic dependence; they had to become independent and autonomous agents (Fatton 1986, 4). This was to be done by blacks in exclusion of whites, who could not be trusted.

The ANC adopted a non-racial and an inclusive approach. This contradicted Africanist and separatist conceptions, but it was an expression of both democratic principles and some elements of class analysis. This was not a symbol of African inadequacy submitting to white arrogance. However, as Fatton $(1986,29)$ puts it, "the insertion of whites in the top leadership of the liberation movement inhibited perhaps the full development of a national and popular revolutionary will. That whites could cut themselves off from their own racist roots to embrace the cause of African freedom, contradicted the existing political reality to such a great extent that the masses must have looked skeptically at this generous democratic impulse." For the PAC, the claim that whites were equals with blacks as citizens, as expressed by the Freedom Charter of the ANC, was to defy the grim reality of white repression and supremacy. This tension led to the Africanist breakaway from the multiracial ANC in 1958 to form the PAC in 1959 (Fatton 1986, 20).

By 1968, black students' displeasure with white dominance of student politics led first to blacks-only meetings, and then to the creation of the exclusively black student organisation, the South African Students Organisation (SASO). Years later, John Sebidi, a Catholic priest and SASO supporter, described that organisation's founding as "a hefty attempt at severing ... the psychological umbilical cord that held the black man to the slow-moving liberal band-wagon." This severance took about a year, starting with a blacks-only caucus in 1968 and culminating with the inauguration of the new organisation with Steve Biko as its first president in 1969 (Magaziner 2010, 26).

By the 1970s, the BCM emphasised not merely race as a decisive factor in the struggle against white supremacy, it also stressed the interracial linkages preserving and enhancing the given racist reality. Thus, class as well as race occupied a privileged position in the BCM analysis of the SA social formation. In this sense, the BCM departed from the purely racial attitude and strategy of Africanism. Being African was not a sufficient condition to qualify as a black; to be black implied a determined antagonism to apartheid and the political will to eradicate it (Fatton 1986, 32). While it is clear that the BCM was deeply influenced by Africanism and had developed an exclusionary policy towards whites, it nonetheless went beyond the confines of race and 
Africanness. Indeed, the notion of "blackness," which decisively moulded the movement's outlook, was embedded in both the consequences of being black in a white supremacist state and the realities of material exploitation derived from racial capitalism. As such, the concept "black" came to encompass all of the exploited, irrespective of their Africanness (Fatton 1986).

Foster (2007, xix), in discussing "reasons for knowing blackness," refers to what he calls, neo-mythic register or registers of knowing. This register suggests that the world is made of different objects with the binary that some are good while others are evil. There are ways of knowing the good from evil. The measurement tool ignored the differences in the appearances of objects, but would know how genuine they are, like knowing the colour of their hearts and their intentions. Once this knowledge is known, it can be used as the basis for an ethical relation, one that is ultimately based on whether specific people or individuals intend to be good or evil towards others.

Plaatjies-Van Huffel $(2020,102)$, as a poststructuralist, held the view that "the affirmation of blackness implies the rejection of traditional definition of the concept 'black'." She thus supported the view of Martin Luther King Jr., namely that the colour of one's skin should not stand as judgement by which to include or exclude people in the service to the oppressed, but the content of their character. She argued that blackness is an ontological symbol and that black identity, like other identities, is not static but socio-dynamic, multiple, textured and a historical construct (Plaatjies-Van Huffel 2020, 101). She believed that blackness as a symbol "can be attributed to people who do not have black skin but who do work for liberation" (Plaatjies-Van Huffel 2020, 102). This means that those who are not ontologically black, such as whites, can be included in the ministry to the victims of oppression.

\section{Plaatjies-Van Huffel and the Framework for a Relevant Ministry in a Situation of Blackness}

What is the framework for ministry in a situation of blackness, i.e. to the victims of oppression? Plaatjies-Van Huffel provided some pointers in this regard. She highlighted a ministry which demonstrates God taking the side of the victims of oppression, who are denied justice and who are wronged. She drove home this point when she interpreted the Belhar Confession, especially article 4. She thus echoed: "It is a confession for the whole church seeking to be faithful to God, who stands in the midst of suffering of any and all expression" (Plaatjies-Van Huffel 2013a, 340). A similar view of God has also been stressed by Boesak $(1988,8)$ :

God's liberation is not an isolated deed, a blinding flash in history that we see today but of which no trace will be found tomorrow. God's liberation, rather, is a movement. It moves through history. Over and over again God is manifested as the warrior who fights for justice. God deals grimly, justly, with the pharaoh [sic] who oppresses Israel; but God deals no less grimly, justly with the wealthy Israelites who offer no justice to their 
poor fellow Israelites ... God's justice or righteousness, therefore, is the liberation, the healing and salvation, that God wills to realise and actualise among us.

Plaatjies-Van Huffel also provided a pointer towards a ministry that guards against the misuse of scriptures for sinister means. This was also seen when she emphasised a section of the Belhar Confession and stated: "The declaration of status confessionis, like in the case of the theological justification of apartheid, becomes necessary when the integrity of the proclamation of the gospel is at stake" (Plaatjies-Van Huffel 2013a, $344)$. This scenario is well outlined by Udeani $(2007,82)$, who states that "efforts were made since the 18th century to find biblical support for the inequality of the races in order to justify the oppression unleashed on the Africans. An anchor for this view was found in the book of Genesis, chapters 9 and 10, where Africans were depicted as the accursed progeny of Ham."

The ministry that understands the nature of the injustice levelled against victims of oppression was highlighted by Plaatjies-Van Huffel. She articulated her understanding of the injustice so well: "Apartheid, in its application through racist structures, led to exclusive privileges for the white section of the population at the expense of the blacks. Apartheid created a situation of injustice and oppression, large-scale deportation to racially segregated group areas and caused havoc to family life and suffering to millions of South Africans" (Plaatjies-Van Huffel 2013b).

A ministry that embraces the fact that issues of injustice are timeless, was part of the highlights by Plaatjies-Van Huffel. She thus pointed out that "the issues of racial inequality, discrimination, oppression, poverty and injustice which are being addressed by the Belhar Confession are timeless and universal themes" (Plaatjies-Van Huffel 2013b, 2).

Plaatjies-Van Huffel (2013b, 2) underlined the ministry of unity, justice and reconciliation in her analysis of the Belhar Confession. She called upon the church to denounce all forms of racism and injustice. The three central themes of the Belhar Confession, namely unity, justice and reconciliation, have a deep biblical resonance for Reformed Christians. Through the Belhar Confession, churches across the globe discern the action of the triune God in their lives and in history, and learn resistance in the face of behaviour that is dehumanising.

The ministry that highlighted the policy of the Alliance of Black Reformed Christians in Southern Africa (ABRECSA), whose main focus was reflection on Reformed faith and its implications for opposing apartheid within and outside the church, was embraced by Plaatjies-Van Huffel. These influenced decisions on what she called "Black DRC on social justice issues during the 1980s" (Plaatjies-Van Huffel 2013a, 339-340).

A ministry that is against gender stereotypes was demonstrated by Plaatjies-Van Huffel. In her congregation of Robertson-Robertson East, there was discomfort by some members about her gender. Almost 120 members, and ironically women, left this 
congregation for Robertson congregation. She, however, continued to serve the congregation for 17 years with distinction, thereby breaking up the stereotypes existing in this conservative community. Flaendorp $(2014,56)$ coins her contribution well: "The legacy she left behind in the congregation and the presbytery of Zuurbraak is immense. There are physical beacons in Robertson that bear testimony to the legacy of this formidable former Robertson-East URCSA minister. She restored not only the dignity of her congregants, but also those of the community."

Plaatjies-Van Huffel embraced a ministry which bears strong elements of empowerment and black consciousness. She started by operating in an apartheid ideology context in SA, where blacks and women in particular were still marginalised. She was also a victim of this situation herself, being part of this vulnerable, marginalised group. Despite this marginalisation, she challenged the status quo by enrolling for a theology degree at the University of the Western Cape, with no guarantee that she would be ordained as a minister in URCSA. She was eventually ordained as the first woman minister in the family of Dutch Reformed churches, after persistent struggles (Flaendorp 2014, 58). The driving force behind her struggle for self-empowerment and empowering others could be located from within the BCM. She highlighted Biko's critique for both white supremacy and the inferiority complex of blacks (Plaatjies-Van Huffel 2020, 104). To support this view, she quoted Biko, emphasising it as follows:

Being black is not a matter of pigmentation - being black is a reflection of a mental attitude. Merely by describing yourself as black you have started on a road towards emancipation, you have committed yourself against forces that seek to use your blackness as a stamp that marks you out as a subservient being.

An example of the positive impact of this type of ministry is evident from the mentorship of Plaatjies-Van Huffel (Flaendorp 2014, 59) to empower the marginalised; namely Bettie Wanza, a deaf woman of Worcester, whom she guided to complete her theological studies and assisted in being ordained as a minister of URCSA. PlaatjiesVan Huffel's success in this empowerment ministry was expressed in her own words, that she "refused to embrace the role of submissiveness" (Plaatjies-Van Huffel 2019, 4). Similar examples of the results of such empowerment can be seen in the activities of the African American civil rights leader, James Meredith (in Ongiri 2009, 1), a nonviolent advocate who in 1966 organised a march and entitled it, "March against fear." The aim of this march was to tear down the fear that gripped African Americans in Mississippi then. Another example of the impact of this type of ministry could be seen from the Roman Catholic Church during the 17th century in colonial Mexico, where the converted mulatto slave, Maria de San Diego (black), took Manuel de Figueroa (white) to court for having taken away her virginity but not marrying her and instead married a woman of his race group (Bennett 2009, 137). This type of ministry was commended by Bennett $(2009,38)$ :

The fact that a young black woman could legitimately stake such a claim in the contours of a rapacious colonial slave society in which all women constituted objects of unbridled 
desire speaks to Maria's Christian consciousness. Christianity made possible Maria's understanding of herself and her body. She conceived of herself as possessing virtue, which was literally embodied in her virginity. Maria also possessed a will that allowed her, not her parents, to decide that Manuel was the man to whom she will surrender her virtue with the promise of a marriage.

Plaatjies-Van Huffel represented a ministry of hope in a situation of despair. She was operating in a situation where women were marginalised in SA, but she carried on with the struggle despite obstacles she encountered (Flaendorp 2014, 55-58). Firstly, she challenged the status quo by enrolling for a degree in theology, even if she was not sure if she would be ordained as a minister. Secondly, she worked in an environment where, through the years, there had been a perception that a minister should be a strong male leader. Congregants thus reduced women ministers to second-hand theologians. Thirdly, despite rejection by the congregation of Robertson-Robertson East on the basis of her gender, she continued to serve them so well for 17 years, breaking gender stereotypes. Fourthly, she was not discouraged by her many unsuccessful applications for academic positions, which might have been rejected because of her gender. Despite all of this, after her appointment at the University of Stellenbosch, she made tremendous contributions. This led Flaendorp to comment about her as follows:

Her appointment came after numerous unsuccessful applications for academic positions at different places of higher education in SA. Her appointment was again a cairos moment for URCSA specifically. Her appointment as senior lecturer in Church History and Church Polity was more than merely a numerical presence for URCSA in the Faculty of Theology, but it also signified a major historical moment in the relationship between the DRC and URCSA and strengthening the ties between the two organisations. (Flaendorp 2014, 58)

Plaatjies-Van Huffel enacted a ministry of organic intellectualism. Botha $(2013,79)$ touches on organic intellectuals when referring to the ministry style of Allan Boesak. He defined this by quoting West, who said that it is the ability to link the life of the mind to social change, or what he called "life of the mind (got) involved in social change." West further disclosed four aspects of this, namely "the prophetic black church tradition, the prophetic liberal Christianity, a prophetic Ghanaian method of nonviolent social change and prophetic American civil religion." Gramsci, the originator of the organic notion, distinguished between two types: 1) traditional intellectuals, who support the ruling class of the time; and 2) organic intellectuals, who were in the struggle against injustice and oppression. Plaatjies-Van Huffel demonstrated organic intellectualism in her ministry. Despite the fact that she was an academic since 2003, when she obtained her first doctorate, followed by her appointment as a lecturer at the University of Stellenbosch in 2010, she succeeded to adjust in serving a poor congregation of Robertson-Robertson East with distinction. Flaendorp (2014, 55) describes this congregation thus: "The newly constituted congregation in East Robertson was a socially deprived and economically poor Coloured community, consisting of farm labourers, seasonal workers and mostly illiterate people." Flaendorp (2014, 56) 
succeeded to discover Plaatjies-Van Huffel's secret around her excellence in praxis in this regard, when he stated: "Her involvement in community upliftment is rooted in her firm belief that the church must act as the hands of God in the world, especially for those in need."

It is interesting that Plaatjies-Van Huffel highlighted and broadened the scope of the identity of the victims of oppression to include those who were not ontologically black. She warned, as she diverted from a black theology platform, that this expression of theology does not only concern itself with the suffering of black people, hence "the awareness of the struggle and suffering of people who are not black-skinned, across the globe, is needed" (Plaatjies-Van Huffel 2020, 103). In light of this, a relevant ministry towards the victims of apartheid is to take this into consideration.

A ministry that carries the marks of the "stigmata of the cross" (suffering), comes to light as a package for ministry towards the victims of oppression (Masuku 2010, 200). Plaatjies-Van Huffel had a taste of this in her congregation of Robertson-Robertson East, where she was rejected on the grounds of her gender (Flaendorp 2014, 56). This resulted in a schism, whereby 120 members (ironically mostly women) who refused to be ministered by a woman, left that congregation. Yet she devised means of servicing them with distinction for 17 years. This aspect of suffering and rejection has been well coined by Masuku $(2010,200)$ in his description of the stigmata of the cross experienced by Dr Beyers Naude, who was a champion for the ministry to the victims of oppression:

This was reflected in his harassment by the security forces, a night in custody, the banning order, rejection by his volk, family, DRC, and friends. It could therefore be concluded on this basis that suffering forms part of the package of ministry to the victims of oppression.

\section{Conclusion}

Difficult questions, seeking answers, were asked at the beginning of this article. The author tried to provide relevant academic responses. The dynamics of "blackness" with regard to the identity of the victims of oppression, as well as the qualifications for ministry to those identified as victims, were addressed in tandem with the thoughts of Plaatjies-Van Huffel.

The meaning of the "victims of oppression" has been explored and explained. It came to light that, having surveyed the debate on the term or concept "blackness" or "black," there are various dynamics attached to how it is understood from different contexts. Plaatjies-Van Huffel's dialogue with theologies of liberation, as her interlocutors in this regard, were helpful in further understanding the issue of "blackness" within the scope of ministry to the victims of oppression. For instance, in her dialogue with black theology, it became apparent that "black" was not only referring to those who were "black skinned" but to others as well, who embrace, understand, support and identify with the experiences of the victims of oppression. She also brought to light that 
"blackness" is not only about the suffering and pain of those who were physiologically or ontologically black, but that it embraced others who tasted the same hardship. It also came to light that the ontology of "blackness" is not the only key to the ministry for the victims of oppression, but that all who understand and fight the same plight of the oppressed, could minister to the oppressed. The framework for a relevant and acceptable ministry to the victims of oppression was crafted as a guide for those who thought they were excluded in rendering a relevant and acceptable ministry to the poor.

In light of the thoughts of Plaatjies-Van Huffel, as observed in this article, her stance on the conundrum of "blackness" in relation to access to the ministry of the victims of oppression, has become clearer. All servants of God, regardless of the colour of their skin, are acceptable in ministry to victims of oppression, as long as they understand and address the victims' plight through a transformative ministry that proclaims a God who is on the side of the wronged. This is where Mary-Anne Elizabeth Plaatjies-Van Huffel stands!

\section{References}

Bennett, Herman. L. 2009. Colonial Blackness: A History of Afro-Mexico. Indiana: Indiana University Press.

Boesak, Allan. A. 1988. Black and Reformed. Apartheid, Liberation and the Calvinist Tradition, 3rd edition. Braamfontein: Skotaville.

Botha, Nico A. 2013. "The Voice of Protest within the Dutch Reformed Mission Church 19761986." In Reformed Churches in South Africa and the Struggle for Justice: Remembering 1960-1990, edited by Mary-Anne E. Plaatjies-Van Huffel and Robert Vosloo, 75-91. Stellenbosch: African Sun Media.

Conradie, Ernst M., and John Klaasen. 2014. The Quest for Identity in so-called Mainline Churches in South Africa. Stellenbosch: African Sun Media.

Curran, Andrew S. 2011. The Anatomy of Blackness: Science and Slavery in an Age of Enlightenment, Johns Hopkins University Press. ProQuest Ebook Central, https://ebookcentral-proquest-com.uplib.idm.oclc.org/lib/pretoriaebooks/detail.action?docID=3318738.

Fatton, Robert. 1986. Black Consciousness in South Africa: The Dialectics of Ideological Resistance to White Supremacy. SUNY Press.

Flaendorp, Charles. D. 2014. "The Life and Times of Professor Mary-Anne Plaatjies-Van Huffel: A Transformative Church Leader in Sub-Sahara Africa." Studia Historiae Ecclesiasticae (August) 40: 53-63.

Foster, Cecil. 2007. Blackness and Modernity: The Colour of Humanity and the Quest for Freedom, MQUP, 2007. ProQuest Ebook Central, https://ebookcentral-proquestcom.uplib.idm.oclc.org/lib/pretoria-ebooks/detail.action?docID=3332024. 
Kritzinger, Johannes N. J. 1988. "Black Theology. Challenge to Mission.” PhD thesis. University of South Africa.

Magaziner, Daniel R. 2010. The Law and the Prophets: Black Consciousness in South Africa, 1968-1977. Ohio: Ohio University Press.

Masuku, Mnyalaza T. 2010. "The Ministry of Dr Beyers Naude: Towards Developing a Comprehensive Mission (Communication) Strategy towards the Victims of Oppression." $\mathrm{PhD}$ thesis. University of Pretoria.

Oduyoye, Mercy Amba. 2001. "Introducing African Women's Theology," vol.6 of Introductions in Feminist Theology. London: A\&C Black.

Oduyoye, Mercy Amba. 2009. Hearing and Knowing: Theological Reflections on Christianity in Africa. Eugene: Wipf and Stock.

Oduyoye, Mercy Amba, and Musimbi, R.A. Kanyoro. 2005. The Will to Arise: Women, Tradition, and the Church in Africa. Eugene: Wipf and Stock.

Ongiri, Amy A. 2009. Spectacular Blackness: The Cultural Politics of the Black Power Movement and the Search for a Black Aesthetic. University of Virginia Press, 2009. ProQuest Ebook Central, https://ebookcentral-proquestcom.uplib.idm.oclc.org/lib/pretoria-ebooks/detail.action?docID=3443990.

Plaatjies-Van Huffel, Mary-Anne E. 2013a. "Reading the Belhar Confession as a historical text." In Reformed Churches in South Africa and the Struggle for Justice: Remembering 1960-1990, edited by Mary-Anne E. Plaatjies-Van Huffel and Robert Vosloo, 329-345. Stellenbosch: African Sun Media. https://doi.org/10.18820/9781920689117.

Plaatjies-Van Huffel, Mary-Anne E. 2013b. "The Belhar Confession: Born in the Struggle against Apartheid in Southern Africa." Studia Historiae Ecclesiasticae 39 (1).

Plaatjies-Van Huffel, Mary-Anne E. 2014. "The Quest for Identity in Reformed Churches. A Gender Perspective." In The Quest for Identity in so-called Mainline Churches in South Africa, edited by Ernst M. Conradie and John Klaasen, 117. Stellenbosch: African Sun Media.

Plaatjies-Van Huffel, Mary-Anne E. 2020. "Blackness as an Ontological Symbol: The Way Forward.” Review and Expositor 117 (1): 101-113. https://doi.org/10.1177/0034637320904718.

Pontinen, Mari-Anna. 2013. African Theology as Liberating Wisdom: Celebrating Life and Harmony in the Evangelical Lutheran Church in Botswana. The Hague: Brill Publishers. https://doi.org/10.1163/9789004245976. 
Reddie, Anthony G. 2014. Working Against the Grain: Re-Imaging Black Theology in the Twenty-first Century. Cambridge: Cambridge University Press.

https://doi.org/10.4324/9781315710952.

Scott, Darieck. 2010. Extravagant Abjection: Blackness, Power, and Sexuality in the African American Literary Imagination. New York University Press. ProQuest Ebook Central, https://ebookcentral-proquest-com.uplib.idm.oclc.org/lib/pretoriaebooks/detail.action?docID=866007. https://doi.org/10.18574/nyu/9780814740941.001.0001.

Tunzi, Zozi. 2020. Interviewed eNCA TV programme African Perspective, 15 July 2020.

Udeani, C. C. 2007. Interculturation as Dialogue: Igbo Culture and the Message of Christ. Amsterdam: Rodopi Publishers. https://doi.org/10.1163/9789401204606. 